\title{
PENGARUH EKSTRAK ETANOL BUAH LABU SIAM (SECHIUM EDULE JACQ.SWARTZ .) TERHADAP KADAR INTERLEUKIN 6 DAN HISTOPATOLOGI PANKREAS MENCIT HIPERGLIKEMIA YANG DIINDUKSI STREPTOZOTOCIN (STZ)
}

\author{
Paska Ramawati Situmorang \\ Staff Pengajar STIKes Santa Elisabeth Medan
}

\begin{abstract}
Background : Diabetes mellitus now becomes a global serious theat with continues encreasingly prevalence. Ethanol extract of squash fruit Chayotte (Sechium edule) is a plant that contains flavonoidsareanti-inflammatory. The objective of this study was to determine the effect of ethanol extract of Squash fruit Chayotte (Sechium edule) to Interleukin 6 level and increasedthe size ofthe diameter of the pancreas in STZ-induced hyperglycemic mice model.

Goals : This research is experimental research uses Post test randomized controlled group design upon male mice, and divided into 4 groups; negative control group, positive control group is treated with streptozotocin at a dose of $60 \mathrm{mg} / \mathrm{kg}$ weight, and groups of therapy (dosage $100 \mathrm{gram} / \mathrm{kg}$ weight, 200 $\mathrm{gram} / \mathrm{kg}$ weight).

Methods : The measurement of the level interleleukin 6 (IL-6) used ELISA method and the description of histopatoligy pancreas. The data analysis of level IL-6 level uses One Way ANOVA $(\alpha=0,005)$ and pancreas histology image used descriptive analysis.

Result : The results showed a decrease in the levels of IL-6, although not significant if it's compared to the positive control. The preparat histopathology pancreas observation increased diameter which showed widening of cell $\beta$ of pancreas.
\end{abstract}

Conclution : The conclusion of this research was that ethanol extract of squash fruit can reduce levels IL-6 and prevent the hiperglikemia mice pancreas damages

Keywords: Diabetes mellitus, Chayotte (Sechium edule), IL-6

\section{Preface}

According to the American Diabetes Association (ADA) in 2010, diabetes mellitus (DM) is a group of metabolic diseases with characteristic hyperglycemia that occurs due to abnormalities in insulin secretion, insulin action, or both ${ }^{[1]}$. General Secretary of the Indonesian Society of Endocrinology (Perkeni) Em Yunir said diabetics in Indonesia in 2030 will reach up to 20-30 million people than in 2007-2008 only about 7 million people ${ }^{[2]}$.

Diabetes treatment using plant extracts ${ }^{[3,4]}$ has been widely used since ancient times in many countries. Nowadays, especially in developing countries, many listed extract plants which are used for diabetes treatment disease like Siam Pumpkin plants. Interleukin 6 (IL-6) has long been used as a marker and as systemic activation of proinflammatory and anti-inflammatory cytokines. Inflammation is the response of a organsme against pathogens and mechanical alteration within the tissue, such as a series of reactions that occur at the site of injury tissue ${ }^{[5]}$. According to Pickup research (2004) IL-6 is an inflammatory mediator that can predict the presence of $\mathrm{DM}^{[6]}$. Squash (Sechium edule) is a plant that belongs to the famili Cucurbitaceae ${ }^{[7]}$.

The components contained in the ethanol extracts of squash analyzed groups of compounds with the color test with several classes of reagents for alkaloids, flavonoids, tannins and polyphenols, saponins, kardenolin and bufadienol, and anthraquinone ${ }^{[8]}$. Flavonoids be useful as antiinflammatory, can protect cell structures, has a synergistic relationship with vitamin $\mathrm{C}$, to prevent bone loss.

\section{The Method of the Research}

This research uses experimental research study design post test randomized controlled group design to male mice and samples were obtained by simple random sampling method. This research 
will measure $\mathrm{kgd}$ as a reference for checking the levels of il-6 and the histology of the pancreas to determine the widening of the size of the pancreatic beta cells where mice were divided into 4 groups: group i: negative control (normal) were not given the treatment, the mice were normal, given only eat and drink excessively (ad libitum) in the cage, group 2: control positive, induced by streptozotocin (stz) at a dose of $60 \mathrm{mg} / \mathrm{kg} / \mathrm{bb}$, group 3 : the treatment group, stz induced by a dose of $60 \mathrm{mg} / \mathrm{kg}$ plus the ethanol extract of squash with dose of $100 \mathrm{mg} / \mathrm{kg}$ and 4 groups: the treatment group, stz induced by a dose of $60 \mathrm{mg} / \mathrm{kg}$ bb plus ethanol extract of squash with a dose of 200 $\mathrm{mg} / \mathrm{kg}$. This study uses phytochemistry laboratory, biology, pathology anatomy and integrated immunology lab of usu Medan.

Experimental Animals: using health active male mice and no defects at 3 months of age, body weight 25-30 grams.

Making the Ethanol Extract: squash cleaned and weighed in fresh state, then cut into small pieces and mashed (blended) like juice. The volume is measured by a measuring glass. Measurement process is done by putting into maserator 10 parts of squash jus, and then pouring 75 parts $(1500 \mathrm{ml})$ ethanol 96\% keep squash closed and leave for 5 days to protect it from the light while stirring occasionally. After 5 days maserat diserkai, the pulp is squeezed and washed with liquid penyari sufficient to obtain 100 parts $(2000 \mathrm{ml})$. Sari (maserat) moved into the closed container. Left in a cool, sheltered from the light for two days. Fluid top (mother ligyor) participated pour and filtered. Extract concentration is done by means of rotary vacuum (rotary evaporator) at $40^{\circ} \mathrm{c}$, then extract is dried with a freeze dryer ${ }^{[9]}$.

Hyperglycemia Induction: animals treatment given stz at a dose of $60 \mathrm{mg} / \mathrm{kg}$ dissolved into 0.1 $\mathrm{m}$ citrate buffer at ph 4.5 injected intraperitoneally ${ }^{[4,10]}$, and later became hyperglycemic mice. Mice were fasted for 18 hours. After 7 days of blood taken from the tails of mice and examined the blood sugar with the expected concentration.

Examination of Interleukin 6 Methods ELISA: This material is used to determine whether there is influence of extracts of squash on levels of interleukin 6 is experiencing a higher number or lower after treated with extracts of fruit squash in a group of $100 \mathrm{mg} / \mathrm{kg}$ and $200 \mathrm{mg} / \mathrm{kg}$ after 28 days.

The Analysis of the Data: Analysis of the data

Paska Situmorang; phone:082160517999; email: was obtained using SPSS for Windows Release. Univariate statistical analysis used mean, standard deviation, bivariate with ANOVA test.

\section{Results and Discussion}

This research has been conducted on the effect of ethanol extract of squash on levels of IL-6 to hyperglycemia induced by STZ and the STZ group with $200 \mathrm{mg}$ extract. Before, this research has received approval from the Ethics Committee Faculty of Math and Natural Sciences of USU Medan.

Blood Sugar Levels (KGD): Induction of STZ given to the positive control group and the group treated with the extract $100 \mathrm{mg} / \mathrm{kg}$ and $200 \mathrm{mg}$ extract / $\mathrm{kg}$ BB. KGD measured to ensure no hyperglycemic mice before induced with STZ. Induction was given by intraperitoneal injection. In the fourth day, mice hyperglycemia with KGD above $250 \mathrm{mg} / \mathrm{dl}$ and this is according to Park and Han (2012) research ${ }^{[10]}$. The KGD assessment committed to whole group P1 (negative control), P2 (positive control), P3 (Extract 100mg / kg) and P4 (Extract $200 \mathrm{mg} / \mathrm{kg}$ ) on the $7^{\text {th }}$ day, $14^{\text {th }}$ day, $21^{\text {st }}$ and $28^{\text {th }}$ day.

The result of the data KGD analysis on the $7^{\text {th }}$ day, $14^{\text {th }}$ day, $21^{\text {st }}$ day and the $28^{\text {th }}$ day showed in the table 1 , table 2 , table 3 , table 4 and table 5 .

The graph in picture 1 . above can be seen that the decline in KGD after induction of STZ occurred significantly in the group given treatment of ethanol extract of squash dose of $100 \mathrm{mg} / \mathrm{kg}$ and $200 \mathrm{mg} / \mathrm{kg}$ on $7^{\text {th }}$ day, $14^{\text {th }}$ day, $21^{\text {st }}$ and $28^{\text {th }}$ day. In negative control group did not occur KGD decline, but, it occurred in the positive, but KGD decreased but not significant.

\section{Discussion:}

The results showed that the extracts of squash at a dose of $100 \mathrm{mg} \mathrm{kgBB}$, and $200 \mathrm{mg} / \mathrm{kgBB}$, can lower blood glucose levels significantly in male mice induced Streptozotocin. A decrease in blood glucose levels due squash extracts that contain flavonoids $^{[11,12]}$.

A number of studies had been done to show the hypoglycemic effects of flavonoids using different experimental models. Plants containing flavonoids had been shown to have a beneficial effect to fight against diabetes mellitus, either through the ability to reduce glucose absorption or through increasing glucose tolerance ${ }^{[13]}$. 


\section{Levels of Interleukin 6 (IL-6) The Result of Research}

Level IL-6 measurements performed on the $28^{\text {th }}$ day after the given extracts of fruit squash in the treatment group. These measurements used the serum of mice with ELISA (Mouse ELISA Kit) method. Implementation procedures performed in the integrated laboratory of USU with $5 \mathrm{x}$ dilution technique to obtain a standard curve with 8 points and incubated at a temperature of $4{ }^{\circ} \mathrm{C}$. Concentration standard curve of IL-6 Elisa Mice are $10-100 \mathrm{pg} / \mathrm{ml}$ with a range of standard curve was $5-500 \mathrm{pg} / \mathrm{ml}$.

Based on the picture 2 it can be seen that the average of levels yield of IL-6 is P1 (negative group) $37.6533 \pm 21.18827, \mathrm{P} 2$ (positive group) $207.9283 \pm 44.40076$, P3 $( \pm 153.4083$ 188.32680), while P4 $(93.8733 \pm 78.04521)$. Statistical test results obtained value of $p=0.057$, significant at $\alpha$ $5 \%$ is not significant ( $p>0.05$ ) we can conclude there is no difference in the average levels of IL- 6 in four groups.

\section{Discussion}

Measurement of interleukin level 6 (IL-6) in mice was conducted on $28^{\text {th }}$ day after given extracts of squash fruit. The levels of IL-6 Measurement performed using Mouse IL-6 Elisa Kit for all groups (negative control, positive control and treatment groups). The study was conducted to compare the group given extract fruit of squash with a positive control. Based on the ANOVA statistical test, it's showed that there was no significant difference in the levels of IL-6 on the whole groups. Although no significant statistical test, but the group P3 (153.4083 pg / ml) and P4 ( $93.8733 \mathrm{pg} / \mathrm{ml}$ ) showed that levels of IL-6 is lower when compared to the positive control (207.9283 pg / ml). This low IL-6 levels shows that the ethanol extract of squash fruit can lower the levels of IL-6 in mice of hyperglycemia. Interleukin-6 (IL-6) is a pleiotropic cytokine with a wide range of biological activities and produced by cells of lymphoid and non-lymphoid that regulates immune reactivity, acute phase response, inflammation and hematopoiesis oncogenesis. According to Pickup research (2004) the longstanding inflammation causes the clinical expression of diabetes and inflammatory mediators that play a role one of which is interleukin-6, a cytokine produced by leukocytes and released into the blood circulation ${ }^{[14]}$. Flavonoids that was found in fruits squash has effect as anti-inflammatory, according to Reynertson research (2007) ${ }^{[15]}$. Interleukin 6 (IL-6) has long been used as a marker for systemic activation of proinflammatory cytokines and anti-inflammatory. Generated recent evidence from mice that eliminated IL- 6 has been shown that IL-6 acts as an anti-inflammatory ${ }^{[5]}$.

\section{Histopathologic Pancreas Research result}

Histopathology of pancreas description was done by measuring the diameter of cell $\beta$ of the pancreas to determine if there are any changes to the diameter of cell $\beta$ of pancreas after a given extract $100 \mathrm{mg} / \mathrm{kgBB}$ and $200 \mathrm{mg} / \mathrm{kgBB}$ when compared to the positive control group (KP) in experimental mice. After the $28^{\text {th }}$ day, the mice were dissected and then the pancreatic tissue was taken, then soaked tissue until completely submerged in alcohol for a fixed. The soaked tissue then making preparations blocks, and cutting the bloking tissue and created a few slides and then smeared on a glass slide with albumin and slowly land affixed to a specimen slide, then slide containing tissue inserted into Haematoxylin solution of 5- 10 minutes for staining and gluing by means dripped as much as one drop of Canada Balsam on deck glass, then the glass was placed over an existing object tissue. Further preparat are labeled, then the tissue was observed with a microscope with a magnification of $100 \mathrm{x}$. Slide of cell $\beta$ of pancreas subsequently seen or read whether there is a decrease or increase in the size of the diameter of the pancreas through a microscope with 100x magnification and the results can be shown in the following figure 3 .

The result of histopathology pancreas was shown in picture $\mathrm{A}$ to be a negative control group (no treatment) where the diameter of cell $\beta$ pancreas was normal (100-400 m). Picture B shows that cell $\beta$ of pancreas was damaged caused by the given induction of Streptozotocin with a dose of $60 \mathrm{mg} /$ $\mathrm{kgBB}^{[10]}$ where size of the pancreas diameter declined as well as the endocrine pancreas space or gap is very large. Picture $\mathrm{C}$ is the group treated with extracts of fruit squash at a dose of $100 \mathrm{mg} /$ $\mathrm{kgBB}$ where the diameter of cell $\beta$ of pancreas is progressing and it loked that there were still pancreas endocrinal space or gap, but not as much or as big as the KP group. Picture D is the group treated with the extract fruit squash at a dose of $200 \mathrm{mg} / \mathrm{kg}$ where the diameter of cell $\beta$ of pancreas also increased diameter which showed widening of $\beta$ cells of pancreas.

\section{Discussion}

The description of pancreas was done by observing an increase in the diameter of cell $\beta$ of pancreas through microscopic magnification $100 \mathrm{x}$. Picture 3 shows the change in the histology of the 
pancreas in the given extracts of squash group (picture C and D) induced by STZ as compared with the one that not given the extract squash group (positive control (Figure B). Cavities or fissures were still seen in the treatment group, but not as many and as found in control positive group. This was caused by the anti imflamational fruit of squash. The results of these observations indicate that squash fruit extract inhibits the cell $\beta$ of pancreas the damage but cannot repair the broken of the pancreas significantly.

The observation result of preparat hispatology pancreas from pancreas of treating mice with the

extract of squash fruit $100 \mathrm{mg} / \mathrm{kgBB}$ and 200

$\mathrm{mgBB} / \mathrm{kgBB}$ showed widening the size of the islets of Langerhans when it's compared with mice positive control group. The number of cells $\beta$ was more, where cells $\beta$ spread all the islets of

Langerhans that showed the larger size of beta pancreas cells and cavities in the area of endocrine pancreas decrease. These changes indicate that the

endocrine cells began to regenerate toward the normal shape. According to Mohan (2013) flavonoids play a role in repairing damage caused by the pancreatic tissue as a result of DNA alkylation can increase the secretion of insulin in the blood and lowering blood glucose levels ${ }^{[12]}$. Flavonoids function as a reducer superoxide anion and radical hydroxyl. Giving the

extracts of squash fruit as anti-oxidants and inflammation can neutralize free radicals in the cell as a result of induction of STZ and the

[1]. Guyton, Arthur, C. and Hall, John, E. Textbook of Medical Physiology, Eleventh Edition. Mississippi: Professor Emeritus Department of Physiology and Biophysics University of ississippi Medical Center Jackson. 2010.

[2]. Martin,S. 2013.JumlahPenderita Diabetes DiprediksiTerusBertambah, (Internet).diakses 3 juli 2014.

[3]. Suryani, N., Aulanni, H. E. Pengaruh Ekstrak Metanol Biji Mahoni terhadap Peningkatan Kadar Insulin, Penurunan Ekspresi TNF- $\alpha$ dan Perbaikan Jaringan Pankreas Tikus Diabetes. Jurnal Kedokteran Brawijaya. 2013. 27 (3).

[4]. Firdous, S.M., Sravanthi, K., Depnath ,R. Evaluation of antiulcer activity of ethanolic extract of Sechium edule fruits in experimental rats [Journal]. Int $J$ Pharm Pharm Sci. 2012. Vol. 4. p. 374-377.

[5]. Janeway, Charles A., Travers, P., Walport, Mark, Shlomchik, M. The Immune System in Health and Disease, Immunobiology, 5th edition.Garland Science. 2001. Section 2-4. inflammatory process that occurs in the pancreas that the damage cell $\beta$ of pancreas caused by free radicals could be inhibited and there is no further damage, according with research ${ }^{[4]}$.

\section{Conclusion and Suggestion Conclusion}

Based on the discussion can be concluded the following:

Ethanol extract of squash (S.edule Jacq. Swartz) can lower blood sugar levels in mice; there was no significant difference by examining the levels of IL-6 in mice by statistical tests, but when compared to the treating group with the positive control group the levels of IL-6 decreased after given the extract of squash (S.edule Jacq. Swartz), observation with histopathology of the pancreas showed a changes in the diameter of the cell $\beta$ of pancreas after administration of ethanol extract of squash fruit (S.edule Jacq. Swartz).

\section{Suggestion}

It is necessary to do the same research by doing preliminary examination to the level IL-6 and some variables that can influence the research result and advance research using larger numbers of samples to result a meaningful statistic test.

\section{BIBLIOGRAPHY}

[6]. Elisabet, Rytter., Bengt, Vessby., Rikard A, Johansson., Clara, Din Anders Sjo., Zetterberg, Abramsson Lilianne., Lennart, Mo"ller and Samar, Basu. Short Communication, Glycaemic status in relation to oxidative stress and inflammation in wellcontrolled type 2 diabetes subjects, British Journal of Nutrition. 2009. 101: 1423-1426.

[7]. Aynin, M. Pengaruh Perasan Buah Labu Siam (Sechium edule (Jacq.) Swartz) Terhadap Penurunan Kadar Gula Darah Mencit (Mus musculus L.) [skripsi]. Jember: Universitas Jember. 2010.

[8]. Marliana, Soerya, D., Venty S., Suyono. 2005. Skrining Fitokimia dan Analisis Kromatografi Lapis Tipis Komponen Kimia Buah Labu Siam (Sechium edule Jacq. Swartz) Dalam Ekstrak Etanol. Biofarmasi [Internet]: diambil dari

URL:http://si.uns.ac.id/profil/uploadpublikasi/ Jurnal/196903131997022001bio_farmasi_6.p df.

[9]. Ditjen POM. Farmakope Indonesia. Edisi ke3. Jakarta. 1979:649, 659, 744, 748, 781-782. 
[10].Park, Me Hua and Han, Ji Sook. Hypoglycemic Effect of Padina arborescens Extract in Streptozotocin- induced Diabetic Mice. Department of Food Science and Nutrition, Pusan National University, Busan 609- 735, Korea. 2012. 17:239 - 244

[11].Siciliano, T., and De Tommasi, N. Study of Flavonoids of Sechium edule (Jacq) swartz (Cucurbitaceae) Different Edible Organs by Liquid Chromatography Photodiode Array Massm Spectrometry [Journal]. J. Agric. Food Chem. 2004. 52:6510-6515.

[12].Mohan, S., Nandhakumar , L. Role of various flavonoids: Hypotheses on novel approach to treat diabetes, Journal of Medical Hypotheses and Ideas. 2014. 8:1-6
[13].Brahmachari, G. Bio- Flavonoids With Promising AntidiabeticPotentials:A Critical Survey, Research Signpost. 2011. p.187-212

[14].Pickup, J.C. Inflammation and activated innate immunity in the pathogenesis of type 2 diabetes. Diabetes Care. 2004. 27:813-823.

[15].Reynertson. Uji efek antiinflamasi ekstrak etil asetat buah jambu mete (Anacardium occidentale L.) terhadap edema pada telapak kaki tikus putih (Rattus Novergicus) dalam Merry, et al., (2013). Uji Efek Antiinflamasi Ekstrak Etanol Daging Buah Labu Kuning (Cucurbita Moschata D.) Terhadap Edema Pada Telapak Kaki Tikus Putih Jantan Galur Wistar (Rattus Novergicus). Jurnal Ilmiah Farmasi.UNSRAT. 2007. 2: 95-115. 